\title{
The equivalence of two open therapeutic regimens of cimetidine in the treatment of acute duodenal ulcer disease: A Canadian multicentre trial
}

\author{
H NAVERT, MD, CSPQ, AP ARCHAMBAULT, MD, FRCPC, \\ IGM CLEATOR, MD, CHB, FRCS, FACSC, FRCSE, FRCS, FACS, NB HERSHFIELD, MD, FRCPC, \\ EJ PROKIPCHUK, MD, FRCPC, ABR THOMSON, MD, FRCPC, FACP
}

\begin{abstract}
One hundred and four patients completed a multicentre study comparing the standard cimetidine regimen of $300 \mathrm{mg}$ qid with cimetidine 600 $\mathrm{mg}$ bid in the treatment of acute duodenal ulcer. Both dosage regimens were effective in alleviating symptoms. At the two- and four-week assessments a significantly greater decrease in frequency, duration and severity of night time pain was recorded in the $600 \mathrm{mg}$ bid group $(\mathrm{P}<0.05)$. The healing rates were equivalent in both treatment groups. After eight weeks of treatment, $96 \%$ of the patients had healed in each treatment group. Cimetidine $600 \mathrm{mg}$ bid may represent a useful alternative therapeutic regimen to the standard $300 \mathrm{mg}$ qid dosage in patients with symptomatic acute duodenal ulcer disease. Can J Gastroenterol 1990;4(2):54-58 (pour résumé, voir page 55)
\end{abstract}

Key Words: Cimetidine, Duodenal ulcer disease, Tagamet

Centre Hospitalier Universitaire, University of Sherbrooke, Sherbrooke, Quebec; Centre Hospitalier Maisonneuve-Rosemont, University of Montreal, Montreal, Quebec; St Paul's Hospital, University of British Columbia, Vancouver, British Columbia; Foothills Hospital, University of Calgary, Calgary, Alberta; St Michael's Hospital, University of Toronto, Toronto, Ontario; and University of Alberta Hospital, University of Alberta, Edmonton, Alberta

Correspondence and reprints: Dr H Navert, 2330 Cohen St, Saint-Laurent (Montreal), Quebec H4R 9 Z7

Received for publication April 27, 1988. Accepted April 7, 1989
Imetidine Suppresses BOTH basal and stimulated gastric acid secretion $(1,21)$ by competitively blocking the action of histamine at the $\mathrm{H}_{2}$-receptors of the parietal cells. Consequently, cimetidine has become a first-line medical therapy for the treatment of peptic ulcer disease.

In North America the standard cimetidine regimen is $300 \mathrm{mg}$ qid. This dosing schedule was established to maximize the pharmacological effect of cimetidine through administration of the drug at times of peak acid production (3). A $24 \mathrm{~h}$ acid suppression study conducted by Mahachai and coworkers (4) indicated that cimetidine $600 \mathrm{mg}$ bid was superior to cimetidine $300 \mathrm{mg}$ qid in suppressing $24 \mathrm{~h}$ in. tragastric acidity and tended to be better after breakfast and overnight. This 


\section{Equivalence de deux régimes thérapeutiques ouverts de cimétidine dans le traitement de l'ulcère duodénal évolutif: Essai canadien multicentrique}

RESUME: Cent quatre patients atteints d'ulcères duodénaux évolutifs ont fait l'objet d'une étude multicentrique comparant un régime standard de cimétidine administrée à la dose de $300 \mathrm{mg}$ qid, d'une part et de $600 \mathrm{mg}$ bid, d'autre part. Les deux schémas posologiques ont soulagé efficacement les symptômes. A deux et quatre semaines, on a relevé une diminution significativement plus grande de la fréquence, de la durée et de l'intensité de la douleur nocturne dans le groupe recevant $600 \mathrm{mg}$ bid $(P<0,05)$. Les taux de guérison étaient équivalents dans les deux groupes traités. Au terme de huit semaines de traitement, $96 \%$ des patients étaient guéris dans chaque groupe. La cimétidine à $600 \mathrm{mg}$ bid représente peut-être un schéma posologique thérapeutique à envisager par rapport au dosage standard de $300 \mathrm{mg}$ qid chez les patients atteints d'ulcères duodénaux évolutifs symptomatiques.

suggested that the regimen of cimetidine $600 \mathrm{mg}$ twice daily should provide adequate gastric acid suppression to promote ulcer healing. Accordingly, a multicentre study in duodenal ulcer patients was undertaken in six Canadian centres to determine if healing rates and symptomatic improvements were equivalent with both therapeutic regimens of cimetidine, $300 \mathrm{mg}$ qid and $600 \mathrm{mg}$ bid.

\section{PATIENTS AND METHODS}

This was an open parallel multicentre trial of two regimens of cimetidine (Tagamet; Smith Kline \& French Canada Ltd), $300 \mathrm{mg}$ qid and $600 \mathrm{mg}$ bid, in the treatment of acute duodenal ulcer. Patients entering the clinics with a suspected diagnosis of duodenal ulcer were considered as potential candidates for entry into the study.

For inclusion, patients had to have an endoscopically confirmed duodenal ulcer measuring between 0.5 and 3.0 $\mathrm{cm}$ at the largest diameter. All subjects had to be between 18 and 70 years of age, and were required to given written informed consent. Protocols were approved by each centre's Ethics Committee on Human Research.

Excluded from the study were patients with concomitant gastric ulcer or esophageal erosions, previous gastric surgery and/or vagotomy, and treatment with cimetidine or other antiulcer drugs for more than one week immediately prior to screening. More specifically, patients who required the continued use of anticoagulants, meto- clopramide, anticholinergics, phenothiazines, anti-inflammatory or salicylate-containing drugs, thiourea derivatives, antineoplastic agents, or systemic corticosteroids were excluded, as were patients who had taken an investigational drug within the past 30 days, pregnant or lactating women, patients with a history of alcohol abuse, and patients with concomitant disease whose symptoms could impair the evaluation of their ulcer disease. Patients who had experienced gastrointestinal bleeding prior to admission had to have been free from frank bleeding for at least $24 \mathrm{~h}$. Documented nonresponders to cimetidine were not to be admitted to the study, nor were patients suffering from severe systemic disease.

Screening assessments included complete medical history, physical examination, endoscopy, laboratory evaluations (hematology, clinical chemistry, urinalysis) and symptomatic assessment. No specific diet was recommended. However, patients were advised to take regular meals and avoid offending foods. Restraint in the use of tobacco, coffee and alcohol was also suggested. Antacid use was permitted but not recommended, and no standard antacids were given to patients; however, antacid consumption was recorded.

Symptomatic assessments were done by interview. Patients completed duplicate visual analogue scales of $100 \mathrm{~mm}$ on which they evaluated by a single pencil stroke the number of episodes, the duration, and the severity of the worst episode for both day and night pain. The scales were marked with figures from 0 (absence of symptoms) to 10 (severe or very long) at each centimetre. Thus, at every assessment, under the direction of the clinical monitor who was unaware of individual treatment, patients completed 12 cards presented to them at random. Patients graded their symptoms of the previous day by marking the symptomatic scale appropriately. They were also questioned about abdominal discomfort, flatulence, heartburn, nausea, vomiting and overall well being.

Assessment of compliance was made by means of a tablet count at each visit. All missing tablets were presumed to have been ingested by the patient. $\mathrm{Pa}$ tients were unaware of these verifications.

All pretreatment assessments were completed within five days prior to commencing therapy. Whenever possible therapy was started on the same day as the first endoscopy. During the screening period, all ulcer therapy was discontinued with the exception of antacids, which could be used for relief of pain. Patients were randomized to receive either the twice daily regimen or the standard $300 \mathrm{mg}$ qid regimen of cimetidine.

As often as possible, the same endoscopist, unaware of the patient's treatment, evaluated the therapeutic effect.

Patients returned at two weeks for a symptomatic assessment, physical examination and compliance check. At four weeks each patient underwent a symptomatic assessment, physical examination, endoscopy, compliance check and repeat laboratory tests. If the ulcer was healed (defined as a return to continuity of epithelium as determined by endoscopy), the study was complete. However, if the ulcer had not healed, the patient was issued an additional four-week supply of medication. At the end of eight weeks patients still in the study returned, and all assessments done at four weeks were repeated. Then, regardless of the endoscopic results, the study was terminated.

Comparability of centres and groups at baseline: Centres were assessed at baseline for comparability by use of a variety 
TABLE 1

Demographic data

\begin{tabular}{|c|c|c|}
\hline & $\begin{array}{c}\text { Cimetidine } \\
300 \mathrm{mg} \text { qid }(n=58)\end{array}$ & $\begin{array}{c}\text { Cimetidine } \\
600 \mathrm{mg} \text { bid }(n=53)\end{array}$ \\
\hline Age (years) & $47.3 \pm 13.6$ & $43.3 \pm 14.2$ \\
\hline \multicolumn{3}{|l|}{ Sex distribution } \\
\hline Male & 35 & 36 \\
\hline Female & 23 & 17 \\
\hline Duration of disease (years) & $8.3 \pm 9.9$ & $5.7 \pm 6.6$ \\
\hline Duration of current episode (weeks) & $4.6 \pm 8.3$ & $5.7 \pm 10.3$ \\
\hline \multicolumn{3}{|l|}{ Family history } \\
\hline Present & 19 & 20 \\
\hline Absent & 39 & 33 \\
\hline
\end{tabular}

of tests as appropriate. In addition, before pooling results, centres were compared for the respective healing rates of their patients. To verify that the population was appropriately randomized, a $\chi^{2}$ test was used to compare sex distribution and family history. The Student's $t$ test was used to compare the groups' age, length of illness and duration of current episode. All tests were two-tailed.

Analysis of healing rates: For the purpose of analysis, patients who had healed at four weeks were considered to be healed at eight weeks.

Analysis of symptomatic assessments: The marks on analogue scales were measured to the nearest millimetre and the mean value obtained from the two readings; the duration of the worst episode, severity of the worst episode and incidence of episodes both for day and night symptoms were logged. The Mann-Whitney test assessed any difference in visual analogue evaluation of the two treatment regimens at baseline and during therapy.

Analysis of compliance: Compliance figures as determined by pill counts for each group was assessed for differences by the Student's $t$ test for the duration of the study.

\section{RESULTS}

A total of 131 patients were considered for analysis in the study. Of these, 111 met the entry criteria. Twenty patients were excluded: 12 from the $600 \mathrm{mg}$ bid group and eight from the $300 \mathrm{mg}$ qid group. They were excluded from the study analysis for the following reasons: seven had severe concomitant disease or previous gastric surgery; in four the ulcer size was outside the allowable range or could not be determined accurately from available records; four had received an investigational drug during the 30 days prior to entry into the study; three had what were judged to be drug-induced ulcers; one was a documented cimetidine nonresponder; and one patient was underage. Thus, 111 patients were eligible for inclusion in the study, provided the demographic data (Table 1) and were evaluated for side effects.

Of these 111 patients, 53 had been randomized to the cimetidine $600 \mathrm{mg}$ bid group and 58 to the $300 \mathrm{mg}$ qid group. Seven patients did not complete the study. Four did not return for follow-up visits; one bled $24 \mathrm{~h}$ after starting the protocol; one was removed at four weeks because of exacerbation of symptoms; and in one, the participating physician was unable to complete the final endoscopy. Thus, the data from 104 patients were available for

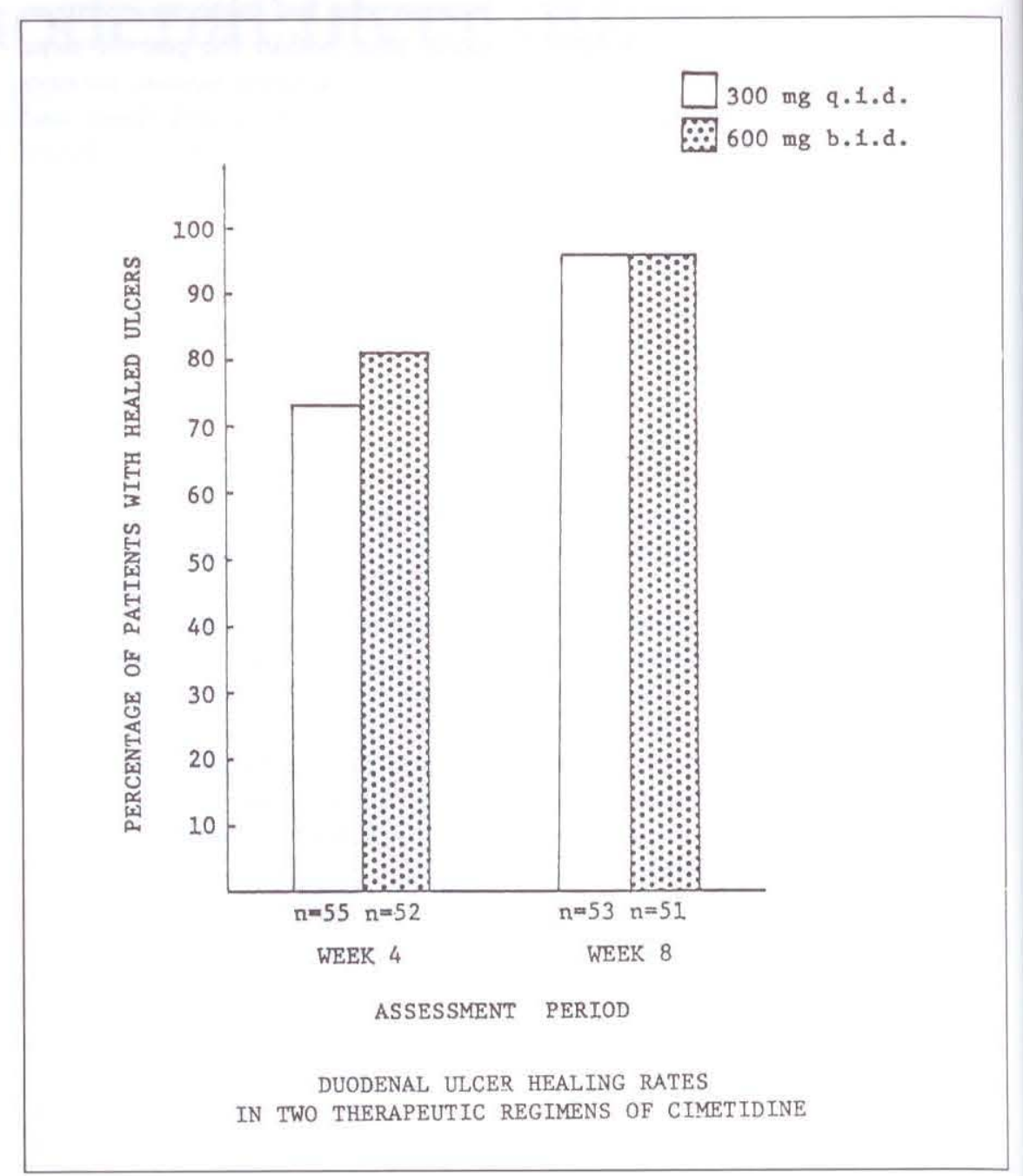

Figure 1) Duodenal ulcer healing rates in two therapeutic regimens of cimetidine. $n$ Number of patients 
TABLE 2

Visual analogue assessment of day pain

\begin{tabular}{|c|c|c|c|c|}
\hline & Pretreatment & Two weeks & Four weeks & Eight weeks \\
\hline \multicolumn{5}{|c|}{ Number of episodes } \\
\hline $\begin{array}{l}\text { Cimetidine } \\
600 \mathrm{mg} \text { bid }\end{array}$ & $\begin{array}{c}21.0(0-99) \\
n=51\end{array}$ & $\begin{array}{c}0.3(0-50) \\
n=51\end{array}$ & $\begin{array}{c}0.1(0-71) \\
n=51\end{array}$ & $\begin{array}{c}1.7(0-30) \\
n=9\end{array}$ \\
\hline $\begin{array}{l}\text { Cimetidine } \\
300 \mathrm{mg} \text { qid }\end{array}$ & $\begin{array}{c}38.0(0-99) \\
n=53\end{array}$ & $\begin{array}{c}0.4(0-70) \\
n=51\end{array}$ & $\begin{array}{c}0.3(0-70) \\
n=52\end{array}$ & $\begin{array}{c}0.3(0-47) \\
n=13\end{array}$ \\
\hline \multicolumn{5}{|c|}{ Duration of longest episode } \\
\hline $\begin{array}{l}\text { Cimetidine } \\
600 \mathrm{mg} \text { bid }\end{array}$ & $\begin{array}{c}30.8 \\
(0-99)\end{array}$ & $\begin{array}{c}0.2 \\
(0-70)\end{array}$ & $\begin{array}{c}0.1 \\
(0-85)\end{array}$ & $\begin{array}{c}1.4 \\
(0-72)\end{array}$ \\
\hline $\begin{array}{l}\text { Cimetidine } \\
300 \text { mg qid }\end{array}$ & $\begin{array}{c}40.3 \\
(0-99)\end{array}$ & $\begin{array}{c}0.5 \\
(0-80)\end{array}$ & $\begin{array}{c}0.3 \\
(0-90)\end{array}$ & $\begin{array}{c}0.4 \\
(0-55)\end{array}$ \\
\hline \multicolumn{5}{|c|}{ Severity of worst episode } \\
\hline $\begin{array}{l}\text { Cimetidine } \\
600 \mathrm{mg} \text { bid }\end{array}$ & $\begin{array}{c}29.3 \\
(0-99)\end{array}$ & $\begin{array}{c}0.2 \\
(0-65)\end{array}$ & $\begin{array}{c}0.1 \\
(0-85)\end{array}$ & $\begin{array}{c}3.3 \\
(0-67)\end{array}$ \\
\hline $\begin{array}{l}\text { Cimetidine } \\
300 \mathrm{mg} \text { qid }\end{array}$ & $\begin{array}{c}40.3 \\
(0-98)\end{array}$ & $\begin{array}{c}0.4 \\
(0-70)\end{array}$ & $\begin{array}{c}0.3 \\
(0-88)\end{array}$ & $\begin{array}{c}0.4 \\
(0-53)\end{array}$ \\
\hline
\end{tabular}

nNumber of patients. All values not statistically significant, $P>0.05$, by Mann-Whitney test. Medians in millimetres; minimum and maximum values in brackets

TABLE 3

Visual analogue assessment of night pain

\begin{tabular}{lcccc}
\hline & Pretreatment & Two weeks & Four weeks & Eight weeks \\
\hline $\begin{array}{l}\text { Number of episodes } \\
\text { Cimetidine }\end{array}$ & $18(0-99)$ & $0.1(0-48)$ & $0.1(0-35)$ & $1.6(0-25)$ \\
600 mg bid & $n=51$ & $n=51$ & $n=51$ & $n=9$ \\
Cimetidine & $25.2(0-99)$ & $0.4(0-94)$ & $0.2(0-70)$ & $0.2(0-58)$ \\
300 mg qid & $n=53$ & $n=51$ & $n=52$ & $n=13$ \\
Mann Whitney test & $N S$ & $P<0.05$ & $P<0.01$ & $N S$ \\
Duration of longest episode & & & & \\
Cimetidine & 22 & 0.2 & 0.1 & 1.4 \\
600 mg bid & $(0-99)$ & $(0-72)$ & $(0-21)$ & $(0-68)$ \\
Cimetidine & 22 & 0.4 & 0.2 & 0.2 \\
300 mg qid & $(0-99)$ & $(0-93)$ & $(0-80)$ & $(0-61)$ \\
Mann-Whitney test & $N S$ & $P<0.05$ & $P<0.05$ & $N S$ \\
Severity of worst episode & & & & \\
Cimetidine & 38 & 0.2 & 0.1 & 1.6 \\
600 mg bid & $(0-99)$ & $(0-51)$ & $(0-41)$ & $(0-50)$ \\
Cimetidine & 28 & 0.4 & 0.2 & 0.2 \\
300 mg qid & $(0-99)$ & $(0-92)$ & $(0-85)$ & $(0-60)$ \\
Mann-Whitney test & $N S$ & $P<0.05$ & $P<0.05$ & $N S$ \\
\hline
\end{tabular}

$n$ Number of patients; NS Not statistically significant, $P>0.05$. Medians in millimetres: minimum and maximum values in brackets

efficacy analysis as described in Figure 1 and Tables 2 and 3.

A separate analysis of the treatment results in both groups of patients (cimetidine $300 \mathrm{mg}$ qid and $600 \mathrm{mg}$ bid) failed to show any appreciable difference between them and the study population, either in endoscopic healing rates, symptomatic relief, or antacid consumption. Their exclusion does not introduce a bias into the study. Baseline data from the six participating centres were evaluated and found to be statistically comparable. No difference in healing rates was found between the centres, thus permitting the pooling of data. There were no significant differences between the treatment groups at baseline for age, sex, family history, length of illness or duration of current episode (Table 1). Although there appear to be differences in the pretreatment median values for some of the visual analogue symptomatic assess- ments, these differences were not statistically significant (Tables 2 and 3 ). The type and severity of other gastrointestinal symptoms were similar for both groups at pretreatment.

Compliance assessment: No difference in compliance was apparent between groups, both having used $97.5 \%$ of the pills distributed.

Symptomatic assessment: Median values for the visual analogue scales at the various rating times are presented in Tables 2 and 3. Both groups showed marked decreases in number of episodes as well as duration and severity of worst episode for both day and night pain at two weeks, with a further diminution of pain as therapy continued. Statistically significant differences in favour of the $600 \mathrm{mg}$ bid regimen were seen at two and four weeks for all night pain values (Mann-Whitney, $\mathrm{P}<0.05$ ). The frequency and severity of other gastrointestinal symptoms also decreased as therapy progressed. Because of the small number of patients at eight weeks, no comparison could be made between the two groups at that time period.

Assessment of healing rates: At week $4,82 \%$ of the patients on the $600 \mathrm{mg}$ bid regimen had healed their ulcers, as compared with $75 \%$ of those on the standard regimen. At week 8 a healing rate of $96 \%$ was recorded for both groups. Thus, there were no differences between the two groups in the population of patients healing on the two treatment regimens.

Consumption of antacids: Antacid consumption was minimal. Only four patients on cimetidine $600 \mathrm{mg}$ used antacids during the study, compared to nine patients on the standard regimen. Side effects: Of the 111 patients who met entry criteria, seven were reported by the investigators to have experienced adverse reactions which, in their opinion, were 'related' or 'questionably related' to cimetidine. There was one report each of leg cramps and headaches in the $300 \mathrm{mg}$ qid group. The remaining reports were from patients taking the twice daily regimen and included headaches and forgetfulness. Additionally, three patients experienced alterations in laboratory parameters which were assessed as 'not clinically significant': a 
slight leukopenia was noted in two patients at the conclusion of therapy, and elevated aspartate aminotransferase and alkaline phosphatase were noted in one patient at the end of the study. No patient had to be withdrawn from the study because of any adverse reaction.

\section{DISCUSSION}

Analysis of findings in this open parallel equivalence study indicate that both dosage regimens of cimetidine 300 $\mathrm{mg}$ qid and cimetidine $600 \mathrm{mg}$ bid are effective in promoting healing and alleviating symptoms in duodenal ulcer. It must be emphasized that this study was designed as an equivalence trial and not an efficacy trial, which would have required approximately 2000 patients at an unaffordable cost. As

\footnotetext{
ACKNOWLEDGEMENTS: Contributing physicians were JN Amar, RJ Bailey, R Beaudry, A Farley, H Haddad, L Halperin, P Lefort, P Leroux, DB Menard, TL Moore, G Pilon, LM Price, EA Shaffer, RW Sherbaniuk, LR Sutherland, RE Warren, RH Wensel. The authors express their gratitude to the numerous clinical and paraclinical personnel from the various centres who made this study possible. In particular they want to acknowledge the assistance and support of the Smith Kline \& French Company, as well as the expertise of Dr M Grace, PhD Eng, of the Department of Medicine, University of Alberta, for his advice on statistics.
}

entry rate into the study as well as funding was diminishing, the study was terminated before recruitment of the targeted 200 patients. Nonetheless, the rate of ulcer healing was comparable in the two treatment groups at four and eight weeks, with similar use of antacids and similar rates of compliance.

Most studies using cimetidine in duodenal ulcer have not shown a clear correlation between symptomatic improvement and healing rates (5-7). The observed superiority of the $600 \mathrm{mg}$ bid regimen in decreasing the frequency, severity and duration of night pain at two and four weeks of therapy is of interest. This observation may be explained in several ways. While in most studies symptomatic assessment was made from diary cards or from interviews covering whole periods (seven to

\section{REFERENCES}

1. Hann RM, Isenberg JI, Maxwell V, Sturdevant RAL. Inhibition of gastric acid secretion by cimetidine in patients with duodenal ulcer. N Engl J Med 1975;293:371-5.

2. Longstreth GF, Go VLW, Malagelada JR. Postprandial gastric, pancreatic, and binary response to histamine $\mathrm{H}_{2}$-receptor antagonists in active duodenal ulcer. Gastroenterology 1977;72:9-13.

3. Longstreth GF, Malagelada JR. Cimetidine suppression of nocturnal gastric secretion in active duodenal ulcer. N Engl ] Med 1976;294:801-4.

4. Mahachai V, Walker K, Jamali F, et al. Comparative effects of two
14 days) between visits to investigators, the present assessment focused specifi. cally on the day prior to each visit. This approach was used on the assumption that patients had a more precise recol. lection of immediate events and on the observation that diary cards are seldom filled out in a consistent manner by patients. It is also likely that the improvement in night symptoms with a higher bedtime dose of cimetidine $(600$ $\mathrm{mg}$ ) reflects a more adequate inhibition of nocturnal secretion than that obtained with the usual recommended $(300 \mathrm{mg}$ ) bedtime dose (4). This observation probably reflects the fact that patients with duodenal ulcer are often night hypersecretors. Thus, these results emphasize the need to control adequately nocturnal hypersecretion in these patients.

cimetidine regimens on 24-hour intragastric acidity in patients with asymptomatic duodenal ulcer. Clin Ther 1984;6:259-81.

5. Ippoliti AF. Cimetidine versus intensive antacid therapy for duodenal ulcer. A multicentre trial.

Gastroenterology 1978;74:383-95.

6. Bardhan KD. Comparison of two doses of cimetidine and placebo in the treatment of duodenal ulcer. A multicentre trial. Gut 1979;20:68-74.

7. Gotthard R, Strom H, Bodemar G, Walan A. Treatment of active prepyloric and duodenal ulcers with antacids/anticholinergics, cimetidine and placebo. Scand J Gastroenterol 1982;17:86-96. 


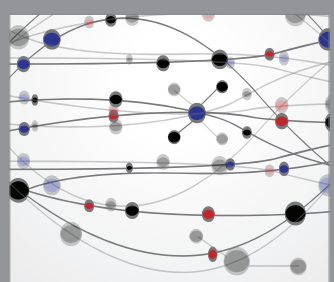

The Scientific World Journal
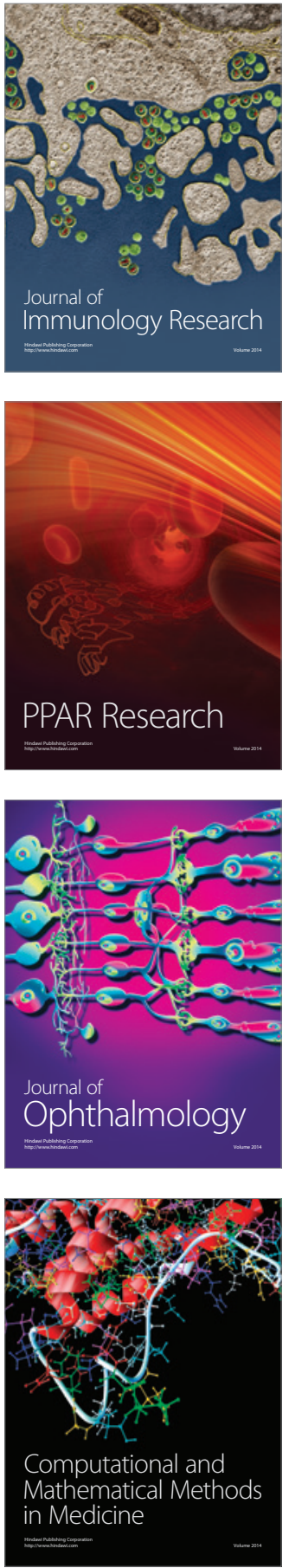

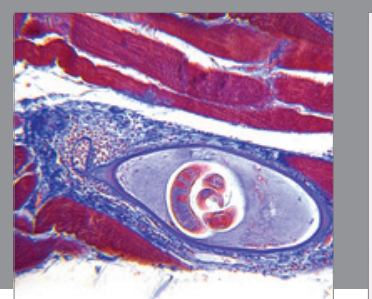

Gastroenterology Research and Practice

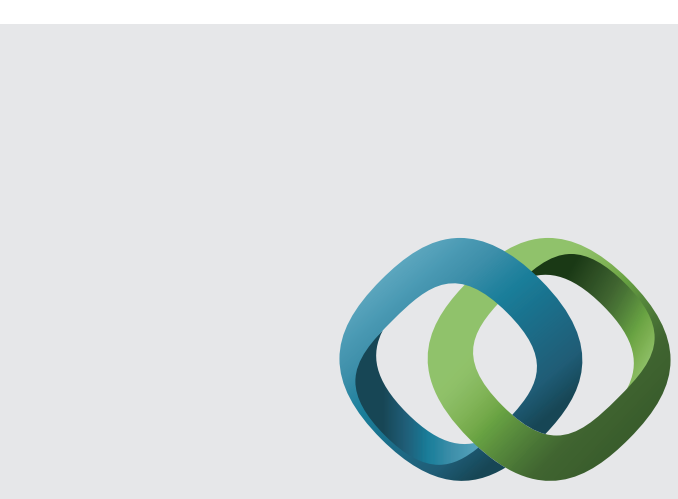

\section{Hindawi}

Submit your manuscripts at

http://www.hindawi.com
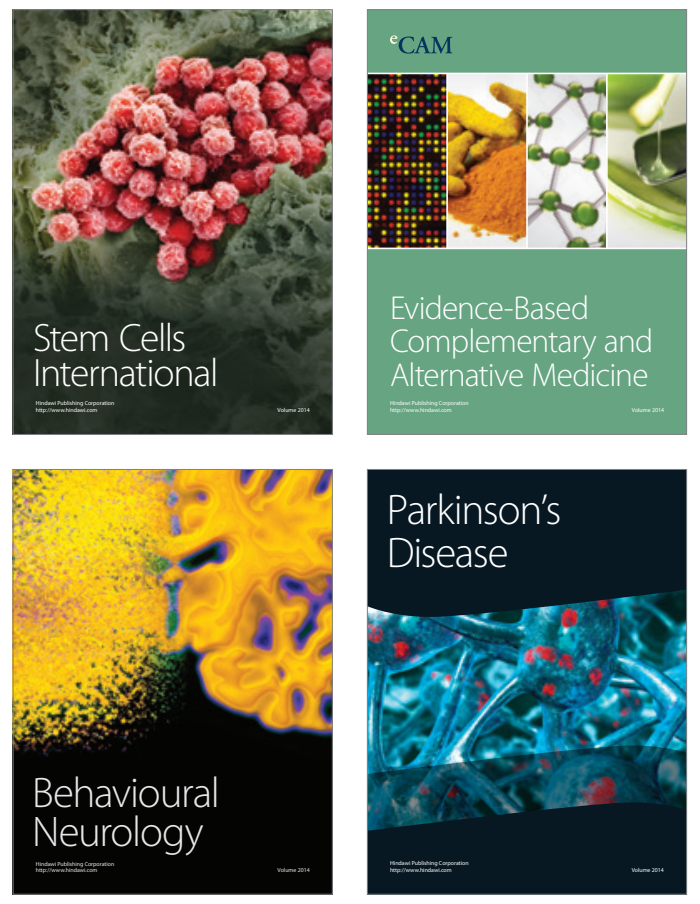
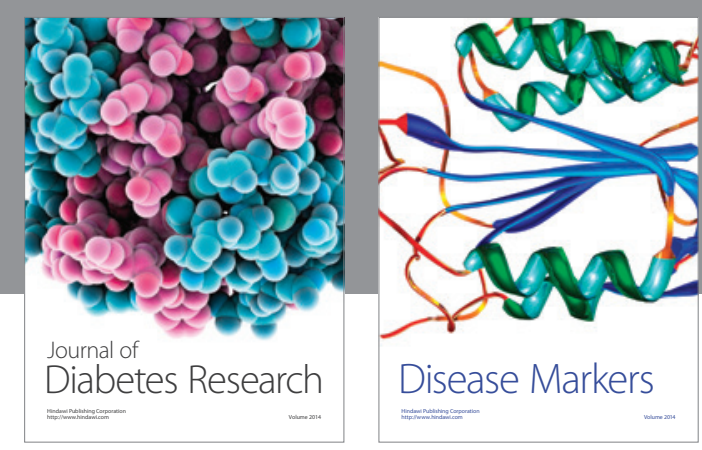

Disease Markers
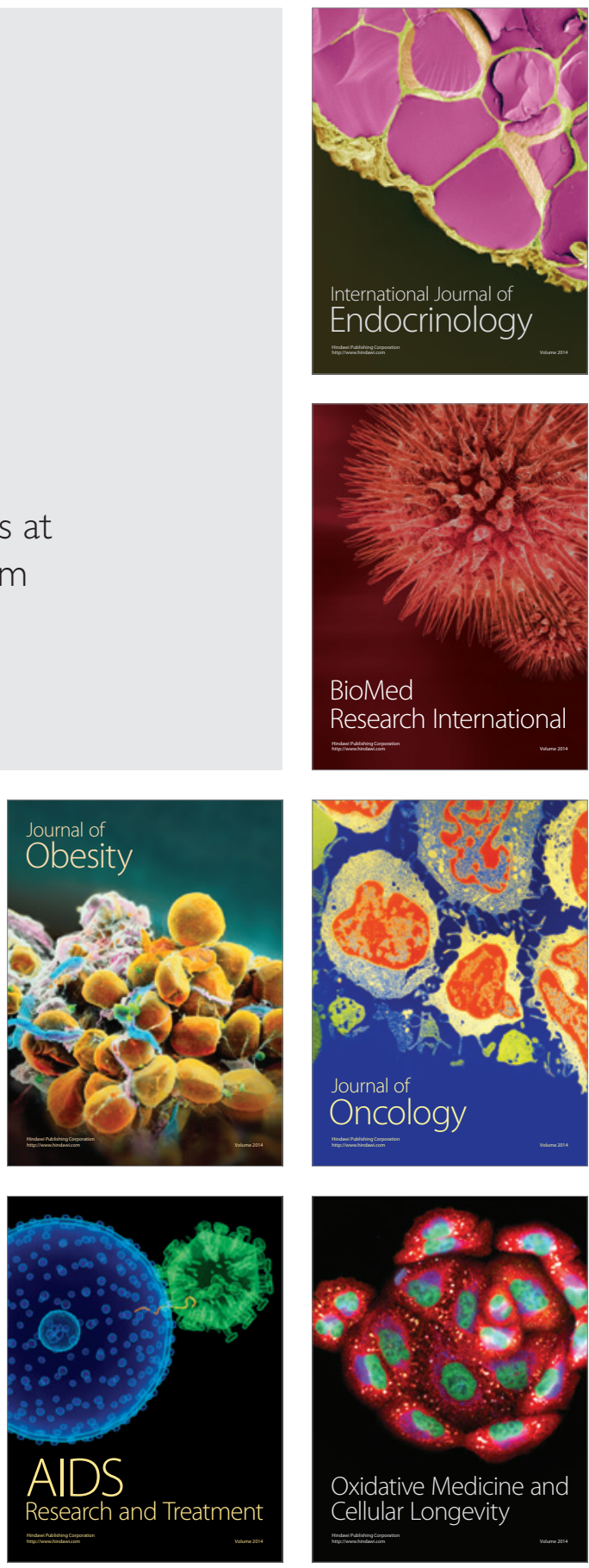